\title{
A DOMINAÇÃO COLONIAL E O SABIR CULTURAL ${ }^{1}$
}

\author{
Pierre Bourdieu \& Abdelmalek Sayad
}

RESUMO

\begin{abstract}
A política francesa de "reassentamento" dos camponeses argelinos, planejada para minar o apoio popular à guerra de libertação nacional (1954-1962), levou ao deslocamento de um quarto da população nativa da Argélia em 1960. Disciplinando o espaço e reorganizando rigidamente a vida dos fellahin, os militares franceses esperavam domesticar um povo, mas isso apenas completou o que a primeira política colonial e a generalização das trocas monetárias já começara: a "descamponeização" de comunidades agrárias despojadas dos meios sociais e culturais para dar sentido ao seu presente e para controlar o seu futuro. Assim, a guerra cumpriu a intenção latente da política colonial, que é desintegrar a ordem social local com o objetivo de subordiná-la, seja sob a bandeira da segregação, seja sob a bandeira da assimilação. Mas a dominação imperial também produz um novo tipo de sujeito que contém em si as contradições nascidas do choque de civilizações: os padrões de comportamento e de ethos econômico importados pela colonização coexistem dentro do camponês argelino expulso de sua terra com aqueles que foram herdados da tradição ancestral, originando condutas, expectativas e aspirações antinômicas. Esta dupla dimensão da realidade, objetiva e subjetiva, ameaçava minar os esforços para socializar a agricultura depois da independência, enquanto que a lógica da descolonização induzia a pequena-burguesia letrada dos burocratas a negar magicamente as contradições da realidade como fantasmas vergonhosos de um passado colonial morto.
\end{abstract}

PALAVRAS-CHAVE: colonialismo, guerra, campesinato, desenraizamento, imperialismo francês, cultura cabila, Argélia.

\author{
Deus deu ao corvo, que naquele tempo era branco, dois sacos: um \\ cheio de ouro, o outro cheio de piolhos. \\ O corvo deu o saco cheio de piolhos aos argelinos e o saco cheio de \\ ouro aos franceses. \\ Foi desde então que ele ficou preto. \\ Tradição oral recolhida em Arba.
}

\section{INTRODUÇ̃̃O}

De todas as transformações que a sociedade rural argelina sofreu entre 1955 e 1962 , aquelas

\footnotetext{
$1 \mathrm{O}$ presente texto é uma tradução de Colonial rule and cultural sabir publicado na revista Ethnography, v. 5, n. 4 , Dec. 2004, p. 445-486, com a gentil permissão de Jérôme Bourdieu e da revista Études rurales. Essa versão baseia-se no ensaio Paysans déracinés, bouleversements et changements culturels en Algérie, Études rurales, v. 12, n. 1, janvier-mars 1964, p. 59-94. Traduzido, a partir das versões francesa e inglesa, por Helena de Freitas Madureira Pinto, José Madureira Pinto e Virgílio Borges Pereira. Adaptação da grafia para o português falado no Brasil: Fábia Berlatto e Bruna Gisi. Revisão técnica da tradução: Adriano Codato e José Szwako. A versão brasileira deste e dos outros artigos difere bastante da versão portuguesa.
}

que foram provocadas pelos reassentamentos ${ }^{2} \mathrm{de}$ populações são, sem dúvida, as mais profundas e as que tiveram maiores conseqüências a longo prazo. Numa primeira fase, os deslocamentos estavam ligados à criação de "zonas proibidas". De 1954 a 1957 muitos camponeses foram pura e simplesmente expulsos das suas aldeias; é sobretudo a partir de 1957 que, em certas regiões, como por exemplo no Norte Constantino, a política de reassentamento assume uma forma sistemática e metódica. De acordo com uma diretriz oficial, o principal objetivo das zonas proibidas era o de

\footnotetext{
2 Literalmente, regrupements, ou "reagrupamentos". Preferimos a expressão "reassentamentos", de uso mais corrente no Brasil (nota da revisão técnica).
}

Rev. Sociol. Polít., Curitiba, 26, p. 41-60, jun. 2006 
“esvaziar uma região não controlada e afastar a população da influência rebelde". O reassentamento em massa das populações em centros situados próximos de instalações militares tinha como objetivo permitir ao Exército um controle direto sobre elas, de maneira a impedir que transmitissem informações, fornecessem orientações, mantimentos ou alojamento aos soldados do Exército de Libertação $\mathrm{Nacional}^{3}$ (ALN); era também uma forma de facilitar a repressão, ao autorizar que fossem considerados "rebeldes" todos aqueles que permanecessem nas zonas proibidas. Na quase totalidade dos casos, a exclusão foi feita à força. No início, o Exército parece ter aplicado sistematicamente, pelo menos na região de Collo, uma tática de terra arrasada: incêndio das florestas, destruição de reservas e de gado - todos os meios foram utilizados para obrigar os camponeses a abandonar sua terra e suas casas:

Claro que teríamos levado muito tempo para demolir as mechtas [povoados] 4 "proibidas" do setor, mas o trabalho acabou por ser muito bem realizado numa área de quatro ou cinco quilômetros quadrados. Primeiro, os homens subiam nos telhados e atiravam as telhas no chão, enquanto outros quebravam moringas, jarros e telhas ainda intactas [...]. No fim do dia, esta técnica, um pouco lenta, já tinha sido aperfeiçoada: grandes quantidades de madeira e gravetos eram amontoados dentro das casas e queimados; em geral, sua estrutura não agüentava e os telhados caíam na hora; aquilo que sobrava era destruído a marretadas (TALBOBERNIGAUD, 1960, p. 719).

Apesar de tudo, a população ofereceu enorme resistência ${ }^{5}$.

3 O ALN (Armée de Libération Nationale) era o braço armado da FLN (Frente de Libertação Nacional da Argélia), fundada no Cairo, em outubro de 1954, na véspera do lançamento de uma insurreição nacional (nota de Ethnography).

${ }^{4}$ Uma observação sobre a tradução e a transliteração de alguns vocábulos: as palavras estreitamente associadas com o Norte da África, i. e., nomes geográficos e étnicos, e, onde não resulta confusão, termos tais como douar que entraram na língua francesa, foram mantidos na sua forma francesa, visto que esta é a mais corrente e a mais padronizada (nestes casos, o som $s h$ é pronunciado $c h, w$ ou $u$ para ou etc.). Termos completamente estrangeiros, por outro lado, são adaptados aos padrões da transliteração inglesa (i. e., shtara em vez de chtara para a forma local de schatâra) (nota da trad. portuguesa).

${ }^{5}$ De acordo com um documento oficial sobre a região de Collo, datado de novembro de 1959 , "8\% da população permaneceu no local, não obstante a proibição [...]. Uma
Muitos [...] devem ter preferido o risco de uma morte violenta ao apinhamento, à sujeição, à morte lenta dos casebres, das tendas e das favelas do reassentamento [...]. As mulheres capturadas pelo conjunto de autoridades da área, conjunto pelo qual a maioria das mechtas foi destruída, eram conduzidas quatro ou cinco vezes até os reassentamentos, mas sempre retomavam o caminho para o seu douar (TALBOT-BERNIGAUD, 1960, p. 711).

Nesta primeira fase, o Exército, inspirado por motivações puramente estratégicas, parecia não ter outro objetivo a não ser esvaziar as zonas difíceis de controlar, sem se preocupar muito com a população evacuada, sem assumir o objetivo explícito de organizar sua realocação e, deste modo, toda a sua existência. Os camponeses arrancados das suas residências habituais foram reunidos como um rebanho em grandes centros, cuja localização tinha sido escolhida por razões exclusivamente militares. É bem conhecida a pobreza material e moral vivida pelos habitantes de reassentamentos tão primitivos como os de Tamalous, Oum-Toub ou Bessombourg, na região de Collo ${ }^{6}$. Nada menos organizado e metódico do que estas ações. Seria vã tentativa encontrar alguma ordem neste turbilhão de reassentamentos anárquicos criados pelas ações repressivas?

fração dos habitantes foi reagrupada em Kanoua, em Bessombourg, em Ain-Kechera, em Boudoukha, em OumToub e em Tamalous. Mais tarde, foram registrados reassentamentos em Boudoukha, Kanoua e sobretudo em Tamalous pelas douars [divisões administrativas rurais] de Taabna, Aïn Tabia e Demnia. Em 1959, 29675 pessoas, $29 \%$ da população total, foram reassentadas. Praticamente os HLL ["hors-la-loi", fora da lei] exercem um controle completo nas zonas interditas, onde as tropas não vão a não ser esporadicamente desde 1958 por falta de efetivos. A população cultiva pomares e pequenas áreas, sobretudo no Oued Zhour; quando a tropa se aproxima, as zribat [zriba (pl. zribat) significa 'clã' no maciço de Collo] fogem e escondem-se no deserto".

6 Vários artigos e sobretudo o relatório de Monsenhor Rhodain (Témoignage et Documents, $\mathrm{n}^{\circ} 12$, maio 1959) descreveram a situação dos reassentados durante os anos de 1958 e 1959 como próxima da dos campos de concentração. Referências dos principais artigos que, nesta época, revelaram o problema dos reassentamentos à opinião pública francesa podem ser vistas em VIDAL-NAQUET, 1961, p. 204-234.

${ }^{7}$ Assim, o relatório do gabinete de desenvolvimento rural da prefeitura de Orléans-ville, publicado em 1961, indica que 185000 "reassentados" do departamento [no original: département], ou seja, $60 \%$ do total, deveriam voltar a suas casas, tão baixo é o nível de vida e as condições sanitárias. 
Os "reassentados" eram completamente subordinados às Seções Administrativas Especializadas $\left(\mathrm{SAS}^{8}\right)$. O Exército, sob a pressão provocada por uma situação que ele próprio havia criado, tinha agora que se preocupar em efetivamente tomar conta de pessoas que, até aquela altura, apenas tinha pretendido neutralizar e controlar. Começou-se a partir daí a "liberação" e o "desagrupamento" da população. Só mais tarde, tem-se a impressão, é que o reassentamento deixa de ser a conseqüência pura e simples da evacuação, para passar a ser o objeto direto das preocupações e mesmo, gradualmente, o centro de uma política sistemática. Apesar da proibição decretada no início de 1959 - de deslocar populações sem permissão das autoridades civis, os reassentamentos multiplicaram-se: em 1960, o número de argelinos reassentados chegava aos 2 157 000, um quarto da população total. Se, além dos reassentamentos, levarmos em conta o êxodo para as cidades, o número de pessoas que se encontravam fora das suas zonas residenciais habituais em 1960 pode ser estimado no mínimo em 3 milhões, ou seja, metade da população rural. Esta transferência da população [argelina] está entre as mais brutais a que a história já assistiu.

\section{OS REASSENTAMENTOS DAS POPULA- ÇÕES E ALÓGICA DO COLONIALISMO}

O essencial é, sem dúvida, agrupar este povo, que está em todo o lado e em lado nenhum. $O$ essencial é pô-lo ao nosso alcance. Quando o conseguirmos, então seremos capazes de fazer muitas coisas que nos são, hoje, impossiveis e que talvez nos permitam apoderarmonos do seu espirito depois de nos termos apoderado do seu corpo.

Capitão Charles Richard, Étude sur l'insurrection du Dahra (1845-1846).

Eu sou da Lorraine, gosto de linhas retas. As pessoas aqui se dão mal com a linha reta. Tenente de Kerkera, 1960.

\footnotetext{
8 As Sections Administratives Specialisées (SAS) [Seções Administrativas Especializadas] eram unidades do Exército preparadas para implementar uma "política de integração" da população argelina nativa. Foram criadas em 1955 em resposta à insurreição pela independência do país. Abrangiam o território argelino ocupando-se de assuntos civis (assistência econômica, social e de saúde) articulados com tarefas militares de informação, manutenção da ordem (o que exigia a proibição reuniões públicas) e minucioso controle da população. Sobre este assunto, ver MATHIAS (1998) (nota de Ethnography).
}

De todas as medidas econômicas e sociais levadas a cabo no quadro da "pacificação", o reassentamento das populações rurais é, sem dúvida, o que melhor se inscreve no prolongamento das grandes leis fundiárias do século XIX, especificamente o Cantonnement (1856-1857), o senatus consultum de 1863 e a Lei Warnier de 1873. O que de fato impressiona é que, embora separados por um século de intervalo, frente a situações idênticas, os funcionários encarregados da aplicação do senatus consultum e os funcionários responsáveis pelos reassentamentos recorrem a medidas semelhantes.

Quer se confessasse cinicamente como "máquina de guerra"9 capaz de "desorganizar a tribo", vista como o principal obstáculo à "pacificação", quer seguisse uma ideologia assimilacionista cujos propósitos eram mais generosos, a política agrária que tendia a transformar a propriedade comum em mercadoria contribuiu decisivamente para desintegrar as unidades sociais tradicionais, ao destruir um equilíbrio econômico em que a propriedade tribal ou clânica constituía a principal proteção. Ao mesmo tempo, facilitou a concentração das melhores terras nas mãos dos colonos europeus através do artifício de concessões e vendas indiscriminadas. As grandes leis fundiárias tinham como função manifesta estabelecer condições favoráveis ao desenvolvimento de uma economia moderna, fundada na empresa privada e na propriedade individual, sendo a incorporação jurídica a pré-condição indispensável da transformação da economia. Mas a função latente dessa política era outra. Num primeiro nível, tratava-se de favorecer a usurpação dos argelinos ao proporcionar aos colonos meios de apropriação aparentemente legais, ou seja, instaurando um sistema jurídico que pressupunha uma atitude econômica e, mais precisamente, uma atitude em relação ao tempo completamente estranhas ao espírito da sociedade camponesa. Num segundo nível, a desagregação das unidades tradicionais (a tribo, por exemplo), que tinham sido a alma da resistência contra a colonização, deveria naturalmente derivar da destruição

\footnotetext{
9 Em 1863 o Capitão Vaissière escrevia: "O senatus consultum de 1863 é na verdade a máquina de guerra mais eficaz que se poderia imaginar contra o estado social dos nativos e o instrumento mais poderoso e mais prolífico que poderia ser posto à disposição dos nossos colonos" (VAISSIÈRE, 1863, p. 90).
} 
das bases econômicas da sua própria integração; e esta era, precisamente, a situação em 1875, que marcou o fim das grandes insurreições tribais ${ }^{10}$.

\section{CAMPONESES SEM TERRA}

Sob a influência conjugada de diversos fatores, a saber, e para citar apenas os mais importantes, a usurpação da terra, a pressão demográfica e a passagem da economia de troca para uma economia de mercado, o campesinato argelino encontrava-se de fato em meio a um processo catastrófico. O recenseamento agrícola de 19501951 mostra que as 438483 propriedades em posse dos argelinos, ou seja $69 \%$ do total, eram inferiores a 10 hectares e cobriam uma área total de 1378464 hectares, ou seja $18,8 \%$ do total, com uma superfície média de 3,1 hectares (em contrapartida, em 1940, esse número era de 4,7 hectares), um valor muito inferior ao mínimo indispensável para a subsistência de uma família camponesa. O número de proprietários de menos de 10 hectares de terra cresceu para cerca de 50 000 entre 1940 e 1950, ou 12\%, enquanto a área das propriedades diminuiu 471000 hectares. Mas, mais profunda foi a transformação sofrida pela estrutura da sociedade rural nos últimos trinta $\operatorname{anos}^{11}$ : entre 1930 e 1954 o número de proprietários de terras diminuiu $20 \%$, enquanto o número de trabalhadores agrícolas, permanentes ou temporários, subiu $29 \%$.

A usurpação da terra e a proletarização também provocaram o abandono de muitas tradições agrárias. É por isso que, por exemplo, a escassez de terras e a pressão demográfica, que impunha o aumento da produção a qualquer custo, levaram muitos fellah'in a desistirem do antigo sistema bienal de rotação: nos anos de 1950-1951, o pousio representava apenas $62,7 \%$ da quantidade de ter-

\footnotetext{
10 Um dos promotores do senatus consultum, A. de Broglie (1860), declarou que esta medida tinha um duplo objetivo: em primeiro lugar, "provocar uma liqüidação geral da terra", com uma parte dela permanecendo nas mãos dos seus antigos proprietários, já não como herança coletiva da tribo, mas como "propriedade pessoal, definida e divisa", sendo a outra parte destinada a "atrair e receber a emigração européia"; em segundo lugar, "desorganizar a tribo", "obstáculo principal” à "pacificação". Poder-se-iam multiplicar os exemplos de declarações no mesmo estilo. V. LACHERAF, 1960, p. 749-756.

11 Bourdieu refere-se aqui ao intervalo entre 1930 e 1960 (nota da revisão técnica).
}

ra semeada. Como prova de que o que se passava era uma inovação forçada e não uma mudança de atitude econômica, a rotação bienal é mais respeitada à medida que as propriedades aumentam. $\mathrm{O}$ mesmo se passa em relação à extensão dos campos semeados em detrimento da criação de gado, que é determinada pela busca de um máximo de segurança. "Muitos fatores influenciam o cultivo das terras", escreve o administrador do distrito misto de Chellala:

"as chuvas irregulares, as geadas da primavera, a natureza rochosa dos terrenos. É duro constatar que a cada ano que passa a agricultura ganha importantes áreas que são destinadas à criação de gado, embora esta última seja mais lucrativa. $\mathrm{O}$ cultivo de cereais não compensa. Apesar das despesas serem poucas, mal permite ao fellah arrecadar a parte de trigo e cevada para consumo próprio. Isso o mantém num estado hipnótico do qual se deve afastá-lo" (SLNA, 1950, p. 32)

Entre os fellah'in que abandonaram o ano do pousio, assim como entre aqueles que lavram as terras de pastagem, é a mesma relação fascinada de medo que inspira comportamentos impacientes e tensos. É certo que o cultivo dos cereais não compensa, mas tudo se resume a produzir para vender no mercado? O que se quer é ter, pelo preço mais baixo, no menor prazo de tempo, o suficiente para alimentar sua família. É portanto sem hesitar que se sacrifica o futuro [futur] da produção, incerto e incontrolável, ao advir [avenir] do consumo, iminente e urgente (BOURDIEU, 1963).

Se nenhum melhoramento veio compensar o empobrecimento do solo causado por uma cultura mais intensiva e se a pressão da necessidade forçou o cultivo de terras medíocres, é fácil perceber porque os rendimentos continuam muito baixos $-4,65$ quintais $^{12}$ por hectare em 1955 . O cultivo da terra anteriormente dedicada ao pousio e às florestas acelerou ainda mais a erosão: entre 1940 e 1954, a área cultivada pelos argelinos diminuiu 321000 hectares sem que a propriedade européia crescesse do mesmo modo; dada a fome de terra dos fellah'in, a possibilidade destas áreas voltarem ao pousio é muito baixa. Assim, podemos considerar que elas foram destruídas pela erosão que lhes roubou dezenas de milhares de

$\overline{12} \mathrm{Um}$ quintal equivale a quatro arrobas (nota da revisão técnica). 
hectares a cada ano ${ }^{13}$.

Que os pequenos proprietários cultivem sua terra sem intervalos, quase até que ela se esgote; que a cevada e o trigo de grão duro, indispensáveis à fabricação de cuscuz e da galette, ocupem $87 \%$ da terra cultivada pelos pequenos agricultores; que a maior parte dos fellah'in se ocupe do cultivo de cereais; que a parte deixada às pastagens, bastante insignificante nas propriedades muito pequenas, aumente à medida que vai aumentando a área total da propriedade: tudo isso prova que a atividade agrícola não tem e não poderia ter outro objetivo que satisfazer necessidades imediatas, não devendo a intensificação da exploração do solo ser atribuída a uma preocupação com o aumento da produtividade, mas à pressão da necessidade. Mais ainda, se o cultivo dos cereais e a criação de gado se mantêm associados seja qual for o tamanho da propriedade - com os donos de áreas superiores a 100 hectares cultivando cereais em rotação bienal e criando gado em regime extensivo -, se a policultura é dominante apenas nas propriedades com menos de um hectare, se o cultivo por conta própria diminui paralelamente à dimensão da terra e se a agricultura argelina, que possui uma área três vezes superior à européia, emprega muito menos assalariados, sejam eles fixos ( 2,4 vezes menos) ou temporários (1,2 vezes menos) e recorre ao Khamessate (tipo de associação característica do espírito e da economia pré-capitalistas) ${ }^{14}$, isso acontece porque a atividade econômica permanece orientada para a subsistência mais do que para a produtividade, com as inovações sendo muitas vezes não mais do que transgressões na tradição, impostas pela miséria. Com mais incertezas do que nunca em relação ao futuro, o fellah assume atitudes cada vez mais inspiradas pela busca da maior segurança possível; quanto mais o presente lhe foge, mais ofellah se agarra a ele, sacrificando todas as atividades que tenham implicações a longo prazo em troca da satisfação direta das suas necessidades imediatas. Para os mais pobres, a

\footnotetext{
13 Encontraremos um quadro sucinto das transformações da economia rural entre 1939 e 1954 em NOUSCHI (1962, cap. V), assim como uma análise esclarecedora do recenseamento da agricultura de 1950-1951 em ISNARD, 1960.

14 "São 64\% das propriedades com pelo menos 100 hectares e $62,8 \%$ da sua superfície que, mal ou bem, estão sob o khamessat" (ISNARD, 1960, p. 58). O khamès é um meeiro que recebe um quinto.
}

providencial previdência, que a tradição exigia, acabou. Uma vez rompidos os equilíbrios tradicionais, se vê desaparecer, juntamente com o mínimo de garantias que o tornava possível, o esforço para se proteger do futuro. Sabendo que, independentemente do que faça, não será capaz de superar esse estado de coisas, o fellah resigna-se a viver um dia de cada vez recorrendo a empréstimos, juntando ao dinheiro que ganha na sua terra o extra recebido por alguns dias de trabalho nas terras dos colonos. Esta improvidência forçada é a expressão de uma total falta de confiança no amanhã, que condena o fellah à capitulação fatalista.

\section{O TRADICIONALISMO DO DESESPERO}

Este tradicionalismo patológico opõe-se ao bom senso da antiga sociedade rural que, por meios tradicionais, assegurava o máximo de previsibilidade dentro dos limites traçados pela precariedade dos meios de produção e da incerteza das condições naturais. Além disso, ele está quase sempre associado, especialmente nas regiões profundamente colonizadas, ao conhecimento e reconhecimento da superioridade dos métodos agrícolas racionais postos em prática pelos colonos. Se os fellah'in continuam a usar o arado de tração manual sabendo qual é a eficiência do arado de tração animal e do trator, se produzem para consumo familiar em vez de produzirem para o mercado, se investem o mínimo possível, se contentam-se com produtos medíocres, se não usam fertilizantes e não mudam, em nenhum aspecto, os seus modos de cultivo, já não o fazem sempre em nome do velho tradicionalismo que a pobreza muitas vezes já solapou. Se recusam melhoramentos a longo prazo, tais como a recuperação dos solos, já não é por não saberem como sacrificar um amanhã [avenir] tangível a um futuro [futur] imaginário; é, acima de tudo, porque não têm os meios para esperá-lo. Embora reconheçam voluntariamente, num nível abstrato e ideal, a maior eficácia das técnicas empregadas pelos colonos e a rentabilidade superior das culturas de mercado, eles são forçados a manter comportamentos tradicionais porque esse tipo de exploração agrícola exige, como eles bem sabem, grandes meios técnicos e financeiros, porque não estão suficientemente seguros da sua própria subsistência para depois buscar o lucro, porque produzir para o mercado é uma aposta arriscada enquanto as necessidades do grupo não estiverem totalmente satisfeitas. "Os colonos", diz umfellah' 
da região de Carnot, "podem produzir para o mercado porque têm assegurado o seu próprio consumo. Podem dedicar-se ao supérfluo porque têm o essencial ou porque têm a certeza que ele não vai lhes faltar". Assim, no lugar de um tradicionalismo tradicional adequado a uma sociedade fortemente integrada e baseada numa economia relativamente equilibrada, surge um tradicionalismo do desespero, inseparável de uma economia de sobrevivência e de uma sociedade desintegrada e apropriada por subproletários presos a um passado que sabem estar morto e enterrado.

Sem outra esperança que não seja colher o suficiente para sobreviver, os mais miseráveis enfrentam a escolha entre esse fatalismo dos desesperados (que nada tem a ver com o Islã) e a migração forçada para a cidade ou para França. Em vez de ser o resultado de uma decisão livre, baseada verdadeiramente na vontade de levar uma vida urbana, este exílio imposto não é senão, muitas vezes, o final inelutável de uma série de renúncias e derrotas: uma má colheita e tem que se vender o burro ou o gado; pede-se emprestado a taxas exorbitantes para equilibrar o orçamento ou comprar sementes; e, por fim, tendo esgotado todos os recursos, não se parte - se foge ${ }^{15}$. Ou então, cansado de tanto penar numa vida tão pobre, parte-se sem destino, deixando a terra a um khammès $^{16}$. Em todos esses casos, a ida para a cidade é uma espécie de fuga para frente determinada pela miséria. Os mais ricos, aqueles que têm alguma poupança, esperam poder se instalar como comerciantes nas pequenas cidades vizinhas que estão acostumados a freqüentar por causa dos mercados. Juntamente com o artesanato tradicional, o comércio é, de fato, o único tipo de atividade adequado a proprietários de terra preocupados em não decair [socialmente], especialmente quando permanecem na região em que são conhecidos por todos:

\footnotetext{
$\overline{15}$ Bourdieu e Sayad usam uma palavra (déguerpit) que é simultaneamente uma expressão coloquial para "fugir, pôrse a andar" e um velho termo legal que significa "abandonar a propriedade e a posse (de uma parcela de terra) com vista a evitar o cumprimento de obrigações" (nota de Ethnography).

16 O recenseamento agrícola de 1950 mostra que muitas pequenas propriedades pertencem a proprietários que não exploram a terra, confiando-a a khammeses.
}

"O que fazer na cidade?", diz um antigo fellah', dono de mais de 20 hectares, que se refugiou em Carnot: "Na cidade, encontram serviço facilmente, como 'lavradores' ou como serventes, aqueles que já trabalharam no douar. Eu não posso ir trabalhar nas fazendas [...] A única atividade que me resta é o comércio, mas é preciso ter recursos".

Por sua vez, os pequenos proprietários expropriados, os antigos khammes ou os trabalhadores agrícolas, despreparados para a vida urbana e que não têm as atitudes ou as aptidões necessárias para se adaptarem a ela, só podem esperar tornaremse diarista, vendedor ambulante ou um desempregado que espera o "paraíso": um emprego fixo"

A guerra, e particularmente os reassentamentos, não só aceleraram a pauperização das massas rurais; os não-assalariados, os proprietários, os khammès, os meeiros, que eram cerca de

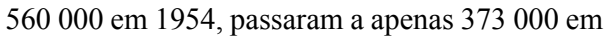
1960, uma diminuição de 33\%. Ao mesmo tempo, o número de assalariados, trabalhadores permanentes e temporários, caiu para 421000 , uma baixa de $28 \%{ }^{18}$. Sem dúvida, parte dessa diferença deve-se ao fato de muitos dos que chamavam a si próprios agricultores ou trabalhadores agrícolas, em 1954, declararem-se desempregados em 1960 , fosse por terem perdido parcial ou totalmente seu trabalho ou por terem adotado uma nova atitude em relação à sua atividade. Mas, além disso, ao completarem a destruição de um equilíbrio econômico precário, ao quebrarem os ritmos temporais e espaciais que formavam a estrutura de toda a existência social, ao pulverizarem as unidades sociais tradicionais, os reassentamentos aceleraram o êxodo em direção às cidades de indivíduos que não têm nada a perder. Entre $1954 \mathrm{e}$ 1960, a população total das cidades e das vilas aumentou $67 \%$ na zona de Argel, $63 \%$ na região de Constantine e $48 \%$ na região de Oran, sendo o tamanho deste aumento resultado da existência de cidades tradicionalmente dotadas de um grande

\footnotetext{
$\overline{17}$ Este ponto é aprofundado em BOURDIEU, 1962; 1973 e em BOURDIEU et al., 1963, p. 303-310 (nota de Ethnography).

18 Cf. BOURDIEU, 1963, $1^{\text {a }}$ parte, p. 83. Se verá que os reassentamentos também aceleraram a formação no mundo rural de uma classe abastada, constituída por camponeses que puderam explorar as terras abandonadas pelos outros porque tinham conservado os meios de produção (gado), por comerciantes e também por funcionários ou empregados nomeados pelo Exército. Algumas famílias dos locais estudados acumulavam esses três tipos de vantagens.
} 
poder de atração, como Argel e, sobretudo, da extensão do reassentamento na região considerada.

Desse modo, a "descamponeização" ("dépaysannisation"), proporcionada pelo reassentamento, foi duplicada pela urbanização que, mesmo temporária, só pôde causar transformações irreversíveis na atitude econômica, ao mesmo tempo em que acelerava o contágio das necessidades: "Tenho muitas necessidades novas", diz um refugiado de Carnot, "é preciso viver como se costuma viver na cidade". Os camponeses recém-instalados são profundamente conscientes deste aumento das privações. Como disse um antigo fellah reassentado em Tlemcen:

"Um fellah que vem instalar-se na cidade habitua-se ao banho mouro, a cozinhar com gás butano. É impossível para ele regressar ao seu douar, onde para cozinhar tem que ir procurar lenha e água a dois quilômetros de distância, e para tomar um banho tem que ir ao canal [wadi]. Eu nasci e vivi na pobreza e sou capaz de viver sempre assim. Mas a nova geração, a geração "atômica"19 já não consegue viver dessa forma. Por exemplo, este aqui (apontando para uma criança de 14 anos) se não tiver a sua costeleta e o seu queijo na hora da refeição, haverá confusão".

Desde a independência tem-se assistido ao efeito do contágio das necessidades que tem sido causado pela urbanização temporária: rádio, gás butano e refrigerador movido a gás multiplicaram-se nas vilas mais remotas (por exemplo, em Aghbala na Pequena Kabylia e em Aïn-Aghbel na Kabylia do Collo).

O contato com a sociedade urbana desenvolveu a consciência das disparidades (sempre crescentes) que separam o nível de vida das cidades e das regiões rurais assoladas pela subnutrição, pobres em recursos de saúde e em escolas. Todos os camponeses que passaram um tempo na cidade puderam viver concretamente o que as estatísticas estabelecem objetivamente, ou seja: que as cidades - especialmente as maiores - oferecem maiores oportunidades de trabalho assalariado, isto é, um trabalho de verdade, ao contrário da agricultura que não proporcionando (ou proporcionando muito poucos) rendimentos monetários aparece como mera ocupação; que as cidades pro-

19 Referência à explosão bem sucedida da primeira bomba atômica francesa em fevereiro de 1960, no campo militar de Reggane no deserto do Saara argelino (nota de Ethnography). porcionam salários maiores e mais regulares (especialmente as grandes, onde as empresas modernas estão concentradas); e que, finalmente, permitem uma vida mais confortável, sendo o consumo urbano muito superior ao consumo rural (por exemplo, 96,45 francos mensais per capita para os comerciantes de municípios urbanos ainda que estes estejam mais próximos dos camponeses -, contra os 65,97 francos para comerciantes das áreas rurais) (DARBEL, 1960). Desse modo, seja de forma indireta, acelerando o êxodo rural e favorecendo a difusão dos modelos urbanos, seja de forma direta, retirando os camponeses das suas condições familiares de existência e provocando uma ruptura decisiva com as rotinas tradicionais, os reassentamentos aceleraram a “descamponeização" já em curso.

\section{DESPREZO E EQUÍVOCOS}

A guerra e a repressão vieram terminar o que a política colonial e a generalização das trocas monetárias tinham começado. As regiões mais significativamente afetadas por essas ações foram aquelas que tinham sido relativamente poupadas até ali, por terem permanecido a salvo da colonização. De fato, foi nas regiões montanhosas que as pequenas comunidades rurais, fechadas sobre si próprias numa obstinada fidelidade às suas tradições, conseguiram assegurar os traços essenciais de uma cultura de que não se pode mais falar a não ser no passado. Foi assim nos Maciços de Kabylia, nas Montanhas Aurès, nas Montanhas Nemencha, nas Montanhas Bibane, nas Montanhas Hodna, no Tell Atlas acima de Mitidja Plain, nas Montanhas Titteri e no Maciço Ouarsenis, onde a cultura tradicional conseguiu manter-se relativamente inalterada, apesar das desapropriações que se seguiram às insurreições, apesar da criação de novas unidades administrativas e muitas outras medidas, apesar, enfim, das transformações impostas pelo simples contágio cultural ${ }^{20}$. Em 1960, as zonas das montanhas onde o Exército de Libertação Nacional tinha se estabelecido com maior rapidez e mais força, assim como as zonas fronteiriças, tinham sido quase totalmente despovoadas; seus habitantes tinham sido

20 Por exemplo, 48 quilômetros a oeste de Orléansville, nas montanhas que dominam o vale do Chélif, zona de grande colonização, a tribo dos Ouled-Ziad perpetuou, graças ao isolamento que o relevo lhe assegurava, todos os traços de uma sociedade tradicional fortemente integrada. 
reassentados nas planícies ou tinham ido para a cidade.

Tudo se passa como se esta guerra tivesse fornecido a ocasião para concretizar até o fim a intenção latente da política colonial, intenção profundamente contraditória: desintegrar ou integrar, desintegrar para integrar ou integrar para desintegrar, eis os pólos opostos entre os quais a política colonial sempre oscilou, sem que a escolha fosse feita claramente e sistematicamente aplicada, de tal forma que intenções contraditórias pudessem animar diferentes responsáveis num mesmo momento ou o mesmo responsável em diferentes momentos. A vontade de destruir as estruturas da sociedade argelina podia mesmo inspirar-se em ideologias opostas: uma, dominada pela consideração exclusiva do interesse do colonizador e por questões de estratégia, tática ou proselitismo, exprimiu-se muitas vezes com cinismo; outra, assimilacionista ou integracionista, que só na aparência era mais generosa.

Para certos funcionários, movidos por uma preocupação dominante, a saber, "subjugar as populações", o papel do Exército é definido pelo "tríptico: proteger, empenhar, controlar". Como escreve Alain Jacob:

Agora, proteger é acima de tudo reassentar. Em cada reassentamento, uma "célula militar", sob o comando de um soldado que deve controlar grupos de trinta a cinqüenta pessoas, dá proteção, faz o recenseamento dos habitantes, cadastra-os e conduz freqüentes interrogatórios. O alistamento depende da "organização" da população, o que pressupõe dispor de funcionários treinados em centros especiais [...]. Enfim, só um controle total e permanente permite que estes métodos dêem frutos (1961, p. 33-34).

Certos "teóricos" da ação psicológica foram ainda mais longe, vendo na desorganização sistemática e forçada a forma de acabar com as resistências.

A esta ideologia dominada por considerações de ordem estratégica e tática opõe-se a ideologia humanitária do imaginário oficial, encarnada no militar graduado das SAS, simultaneamente mestre-de-obras, professor, prefeito e, algumas vezes, médico; ao instalar, em aldeias providas de equipamentos comunitários e situadas perto de grandes eixos/centros de comunicação, populações que até então viviam em habitações dispersas ou em regiões remotas e que, portanto, era muito difícil e dispendioso cuidar, escolarizar e administrar, a intenção era desencadear uma "evolução acelerada". Em suma, originariamente considerados como uma forma de "reagrupar" e "controlar" as populações, colocando-as próximas de um posto militar, os reassentamentos começaram gradualmente a ser considerados por alguns como um "fator de emancipação", sendo a confusão entre os dois fins justificada e encorajada pela convicção de que, para quebrar as resistências desta sociedade, não havia melhor técnica do que destruir suas estruturas ${ }^{21}$. Na verdade, qualquer que fosse a intenção dos indivíduos, a ação "humanitária" permanecia objetivamente como uma arma de guerra, orientada para o controle das populações.

Não foi por acaso que o colonialismo encontrou o seu último refúgio ideológico no discurso integracionista: com efeito, o conservadorismo segregacionista e o assimilacionismo só na aparência se opõem. Num dos casos, invocam-se as diferenças de fato, de forma a negar a identidade de direito e, no outro, negam-se as diferenças de fato em nome da identidade de direito. Ou então se atribui dignidade humana, mas só ao Francês virtual; ou trata-se de recusá-la, invocando a originalidade da civilização magrebina - mas originalidade inteiramente negativa, definida por aquilo que falta.

Prisioneiros dos interesses da colonização ou daquilo que Ruth BENEDICT (1934) chama "a imponente universalidade da civilização ocidental”, políticos e funcionários (burocratas ou militares) não conseguem conceber generosidade maior do que garantir aos argelinos o direito de serem o que devem ser; ser o que, à imagem do europeu, os conduz a negar o que de fato são, na sua originalidade de homens particulares, participantes de

\footnotetext{
21 Num memorando do General Crépin, com data de 7 de abril de 1960, lê-se: “Assim, as preocupações militares conjugam-se com considerações de ordem política e humanitária para instituir reassentamentos viáveis" (apud JACOB, 1961, p. 35). A confusão de objetivos contraditórios era favorecida pela situação como um todo: a política de reassentamento assumia-se como uma tarefa positiva, a um tempo "humanitária" e eficaz, por oposição à ação frustrante da pacificação; e permitia justificar uma visão maniqueísta da guerra revolucionária, face à ação bem-intencionada do Exército respondendo às "destruições" dos "rebeldes". Isso permitia que muitos sentissem que havia nessas ações uma conciliação entre moral e política.
} 
uma cultura singular. Pode-se, então, em nome das mesmas racionalizações, deixá-los como são, abandoná-los para subordiná-los, ou concederlhes a dignidade de existirem, na condição de deixarem de ser o que são.

Raiz comum do assimilacionismo e do colonialismo, a recusa (consciente ou inconsciente) de reconhecer a Argélia como cultura original e como nação serviu sempre de base a uma política de intervencionismo indiscriminada e inconseqüente, ignorante da sua força e da sua fraqueza, capaz de destruir a ordem pré-colonial, sem conseguir substituí-la por uma ordem melhor. Esta política que, associando cinismo e inconsciência, determinou a ruína da economia rural e o colapso da sociedade tradicional encontra seu coroamento nos reassentamentos.

Embora a iniciativa mais ampla tenha sido deixada, na maior parte dos casos, às autoridades subalternas, os reassentamentos são todos parecidos no essencial, porque nasceram menos da obediência a uma doutrina explícita ou implícita do que da aplicação de modelos inconscientes aqueles que, um século antes, dominaram a fundação de aldeias coloniais. A Argélia foi o terreno experimental no qual o espírito militar, como num teste projetivo, assentou suas estruturas. Freqüentemente dotados de uma autoridade absoluta, os quadros do Exército decidiam tudo: a localização da aldeia, o seu traçado, a largura das ruas, a disposição do interior das casas. Ignorando ou querendo ignorar as normas e modelos tradicionais, pouco preocupados em consultar a população que, caso desejasse participar, teria esse desejo tacitamente recusado, impuseram a sua ordem, sem se aperceberem, muitas vezes, do malestar e da desordem que suas iniciativas suscitavam.

À maneira do colonizador romano, os oficiais encarregados de organizarem os novos assentamentos começavam por disciplinar o espaço como se, através dele, pudessem disciplinar as pessoas. Tudo era padronizado e alinhado: construídas de acordo com normas impostas em locais impostos, as casas eram dispostas, em linha reta, ao longo de ruas largas que desenhavam o traçado de um castrum romano ou de uma vila colonial. No centro, a praça com as três características das pequenas cidades francesas: a escola, a câmara municipal, o monumento aos mortos. E pode-se pensar que, se não fosse a falta de tempo e de meios, os oficiais das SAS, apaixonados pela geometria, teriam também submetido a zona rural à centuriação.

Graças à ignorância deliberada ou inconsciente das realidades sociais, as autoridades locais freqüentemente impunham aos "reassentados" uma ordem absolutamente estranha, uma ordem para a qual não foram feitos e que não fora feita para eles. Encorajados pelo sentimento de realizarem um grande desígnio, ou seja, "fazer as massas evoluírem", excitados pela paixão de ordenar e criar, por vezes empenhando todo o seu entusiasmo e todos os recursos nessas ações, os altos funcionários aplicavam ipsis literis esquemas inconscientes de organização que poderiam pertencer à essência de qualquer empreendimento de dominação sistemática e total. Tudo se passava como se o colonizador adotasse, instintivamente, a lei antropológica que diz que a reorganização do habitat, uma projeção simbólica das estruturas mais fundamentais da cultura, conduz a uma transformação generalizada do sistema cultural. LéviStrauss notou que os missionários viam na transformação imposta do habitat dos Bororo o meio mais seguro para obter sua conversão (LEVISTRAUSS, 1955, p. 229; v. também BASTIDE, 1960, p. 114-115). A reorganização do espaço habitado é então encarada inconscientemente como uma maneira definitiva de fazer tábua rasa do passado, impondo uma forma de existência nova, ao mesmo tempo em que imprime no solo a marca da posse ${ }^{22}$. Se a política dos reassentamentos obteve entre os militares uma adesão tão ampla e tão entusiástica, é porque realizou um sonho tão antigo quanto a colonização, isto é, o de "modificar" - como o general Bugeaud disse há um século atrás - ou "reestruturar" - como os coronéis disseram nos anos 1950 - uma sociedade inteira. Mostefa Lacheraf cita o capitão Richard que, em

\footnotetext{
${ }^{22}$ Era essa a intenção quase explícita da centuriação romana, "um verdadeiro sistema de coordenadas traçadas no espaço": "Pelo menos no início da colonização, Roma fez tábua rasa do passado, impondo uma nova estrutura às áreas conquistadas. Fosse por indiferença ou desprezo, ignorava-se a organização administrativa pré-existente e definia direitos de domínio claros, delimitando sua conquista: a posse é como que gravada no solo. De acordo com o eterno princípio político de 'dividir para reinar', vê-se a centuriação isolar as zonas de resistência, isto é, os maciços cujas encostas vai dominando" (CHEVALIER, 1961, p. 76).
} 
1845, preconizava o reassentamento massivo das populações argelinas:

A primeira coisa a fazer para retirar o controle dos agitadores é reunir os membros dispersos do povo, organizando todas as tribos subjugadas por nós em zemalas $^{23}[\ldots]$. Os vários douares seriam separados uns dos outros por uma cerca de jujubeiras selvagens ou uma cerca de quaisquer outros arbustos. Por fim, a zemala inteira seria cercada por um largo fosso cheio de $\operatorname{cactos}^{24}$

Os elementos invariáveis e recorrentes da política colonial não têm nada de surpreendentes: uma situação que tem permanecido idêntica e que lança mão dos mesmos métodos há um século, apesar de algumas diferenças superficiais. A política de reassentamentos, uma resposta patológica à crise mortal do sistema colonial, fez explodir, à luz do dia, a intenção patológica que habitava o sistema colonial.

\section{O SABIR CULTURAL}

Para aqueles que, querendo diferenciar-se, adotavam de forma ostentatória certos hábitos ocidentais, os mais velhos, enquanto guardiões da tradição, reservavam esta tirada: "Ele quer andar com os passos da perdiz, [mas] esqueceu-se dos passos da galinha". Hoje em dia, é todo um povo que, incerto sobre como prosseguir, tropeça e hesita. A lógica mesma da situação colonial produziu um novo tipo de homens e mulheres, que podem ser definidos negativamente, pelo que não são mais e pelo que ainda não são, camponeses "descamponeisados" [paysans dépaysannés], seres auto-destrutivos que trazem consigo todas as contradições.

A ruptura com a condição camponesa e a traição do espírito camponês são o apogeu de um processo essencialmente negativo que leva ao abandono da terra e à fuga para a cidade, ou à permanência resignada numa condição desvalorizada e desvalorizante, mais do que à invenção de um novo tipo de relação com a terra e com o trabalho da terra. Os camponeses "camponeisados" [paysans empaysannés] desapareceram para sempre, mas os agricultores modernos são ainda poucos e raros. Em cada aldeia ainda restam alguns

\footnotetext{
23 Zemala em árabe padrão significa "camaradagem", "companheirismo" (nota de Ethnography).

24 Charles Richard, Etude sur l'inserruction du Dahra (1845-1846), apud LACHERAF, 1960, p. 780-781.
}

camponeses "genuínos" ["naïfs"] que perpetuam teimosamente uma forma de vida obsoleta, e alguns agricultores capazes de gerir suas propriedades segundo as regras da racionalidade econômica. No entanto, a oposição entre o camponês tradicional e o camponês moderno não tem senão um valor heurístico e apenas define os pólos extremos de um continuum de condutas e atitudes separadas por uma infinidade de diferenças infinitesimais.

\section{A COEXISTÊNCIA DOS CONTRÁRIOS}

Esse problema não é um desafio à análise científica? Não estaremos condenados a simplesmente justapor descrições tão contraditórias quanto o objeto descrito? É, de fato, tentador (e muitos fizeram apenas isso) selecionar, com base em interesses e valores tácitos ou explícitos, um ou outro aspecto oposto de uma realidade contraditória para concluir ou que o camponês argelino esteja irrevogavelmente condenado ao arcaísmo, ou que ele possa vir a ser o suporte de expectativas e ideais revolucionários. Numa propriedade agrícola em regime de autogestão, os esforços para aumentar a produtividade são comprometidos pelas velhas tradições de solidariedade. Elas levam os trabalhadores a trazerem para perto de si os parentes desocupados, o que aumenta enormemente a desproporção entre a produção e a mãode-obra empregada ${ }^{25}$. Numa outra, a tentação é grande entre os camponeses recém-instalados,

\footnotetext{
25 Numerosos exemplos análogos de transferência de padrões de comportamentos tradicionalistas para a lógica moderna já podiam ser observados nas SCAPCOs [Séctions Coopératives Agricoles du Plan de Constantine] e nas fazendas da CAPER [acrônimo para Caisse pour l'Acession à la Propriété et à la Exploitation Rurale, Fundo para o acesso à propriedade e à exploração rural]. Por exemplo, um "regroupé" (um camponês reassentado) originário de Aïn-Sultan, sem dúvida demasiado idoso para se tornar um cooperado, julgava-se autorizado a proclamar-se fella h' ocupado "em tempo integral", porque, apesar dos regulamentos da CAPER impedirem a utilização de mão-de-obra fora da própria família, ele ajudou o seu irmão mais novo a explorar a pequena propriedade que adquiriu por intermédio do Fundo. A solidariedade familiar, os hábitos da propriedade comum (momentaneamente abolida pelas circunstâncias que determinaram a dispersão da família, mas que nunca foi expressamente abandonada pelos próprios irmãos) sobrepuseram-se quer às interdições draconianas (como as de abandonar o reassentamento), quer às medidas aparentemente inspiradas pelo cálculo e pela racionalidade econômica (exploração exclusivamente familiar dos lotes
} 
para resolver a contradição da mesma maneira que os trabalhadores agrícolas permanentes das propriedades coloniais, ou seja, subtraindo à exploração racional uns pedaços de terra que serviriam de suporte a ilhas de tradicionalismo e que fariam coincidir a exploração e a posse jurídica. Mas os mesmos trabalhadores podem também, em nome da lógica oposta, protestar contra a equalização de salários que abole toda a correspondência entre a qualidade e a quantidade do trabalho prestado e o produto desse trabalho; em alguns casos, podem mesmo agir de acordo com a lógica estrita do cálculo racional e reduzir o seu esforço proporcionalmente à redução da renda ${ }^{26}$. É claro que, mais do que qualquer outra, essa realidade multifacetada arma suas ciladas às mentes apressadas ou preconceituosas.

Em todos os domínios da existência, em todos os níveis da experiência encontram-se as mesmas contradições sucessivas ou simultâneas, as mesmas ambigüidades. Os padrões de comportamento e o ethos econômico importados pela colonização coexistem, em cada sujeito, com modelos e ethos herdados da tradição ancestral. Daqui decorre que comportamentos, atitudes ou opiniões aparecem como fragmentos de uma linguagem desconhecida, incompreensível tanto àquele que não conhece a linguagem cultural da tradição, quanto àquele que se refere unicamente à linguagem cultural da colonização. Às vezes, são as palavras da linguagem tradicional que são combinadas segundo a sintaxe moderna; outras vezes, o oposto, e por vezes é a própria sintaxe que

da CAPER). É também por referência à lógica da sociedade tradicional que se pode compreender a atitude dos "agricultores do domínio de Saint-Yves que aceitaram a fixação de duas famílias na mesma unidade de cultivo", e não, como tende a pensar o relator da Comissão de Renovação Rural, pelo entusiasmo que suscita a reforma realizada pela CAPER (cf. JORF, 1961, p. 234). [Essas duas formas cooperativas de uso da terra patrocinadas pelo Estado estão mais bem explicadas na referência 30 . Nota de Ethnography].

${ }^{26}$ Seria fácil multiplicar exemplos semelhantes: nos moinhos Amirouch d'Elharrach, depois de um mau começo, o comitê de gestão é apoiado por um conselho de técnicos que se esforça para consertar a situação; o livro de pedidos é preenchido para o ano todo e há capital de giro no montante de um milhão de francos. Sabendo disso, os trabalhadores ameaçaram interromper seu trabalho e exigir que se divida o montante, dizendo que "regressariam ao trabalho quando precisassem de dinheiro". aparece como o produto de uma combinação.

Um exemplo: a sociedade tradicional via o trabalho como uma função social, um dever, obrigatório para qualquer homem preocupado com sua honra, perante si próprio e perante o grupo, e isto independentemente de qualquer consideração relativa ao lucro ou à renda. Segundo a economia capitalista, o trabalho tem a função primária de proporcionar um rendimento monetário e obedece, portanto, à lógica da produtividade e da rentabilidade. Entre os subproletários das cidades e entre os camponeses proletarizados do interior, a atividade se torna uma mera forma de manter-se "ocupado", um meio de fazer alguma coisa ao invés de coisa nenhuma, para ganhar muito pouco ou nada: ela não pode, portanto, ser completamente interpretada quer sob a lógica do interesse e do lucro, quer sob a lógica da honra. Tal como as formas ambíguas da Gestalttheorie, pode ser alvo de duas leituras muito diferentes, dependendo do quadro de referência usado para interpretá-la ${ }^{27}$. Mas a ambigüidade não está na apreensão do objeto; ela reside no próprio objeto: a exemplo do que ocorre com o subproletário, quando o camponês ocupado de forma indigna vive, pensa ou julga sua própria condição, ele constantemente toma por referência duas lógicas diferentes e mesmo opostas. Daqui decorre que cada uma das descrições unilaterais da realidade é suficiente para dar conta de toda a realidade, exceto para o que constitui a sua essência, ou seja, a contradição. Assim, para captar adequadamente uma realidade objetivamente contraditória, é necessário recorrer, simultaneamente, a duas grades de leitura contraditórias: a fidelidade a uma realidade contraditória impede que se escolha entre os aspectos contraditórios que encobrem o real.

Os trabalhadores agrícolas que viviam diretamente nas propriedades dos colonos encontravam nessa duplicidade um modo de escapar à contradição que inelutavelmente decorria da sua participação em dois universos estranhos. Os mesmos que, tal como os tratoristas, os podadores das vinhas ou os jardineiros, trabalhavam nas terras do colono usando os métodos de trabalho mais racionalizados e com as técnicas mais modernas, revertiam às práticas agrárias mais tradicionais para

${ }^{27}$ Para os detalhes destas análises, ver BOURDIEU et al., 1963, II ${ }^{\mathrm{a}}$ parte, cap. 1. 
cultivar os pedaços de terra que o colono lhes cedia nos confins da sua propriedade: a aragem da terra era feita com uma junta de bois formada, freqüentemente, com recurso ao contrato tradicional de sociedade (charka); muitas tarefas uniam todo o grupo segundo as regras costumeiras da ajuda mútua (twiza) e a maior parte das obrigações ocupava a totalidade da mão-de-obra familiar, mulheres e crianças incluídos. Os produtos da lavoura, destinados ao consumo familiar, consistiam quase exclusivamente em cereais, cultivados sem esterco ou fertilizante. As colheitas eram tão fracas como as das terras montanhosas, ou seja, 400 ou 500 quilos por hectare ${ }^{28}$. Enfim, ninguém pensava em incluir em sua atividade como fellah as preocupações do trabalhador agrícola e, por exemplo, inquietar-se sobre a relação entre a quantidade e a qualidade do esforço empregado e o produto do trabalho. Não era diferente com aqueles que, tendo permanecido fellah 'in, eram contratados periodicamente nas propriedades coloniais. Este dualismo se expressava em todos os domínios da existência, quer se tratasse da vida religiosa, das atividades de lazer ou das trocas matrimoniais: uma ilha de tradicionalismo patológicoquer dizer, excessivo e descontextualizado - viase transportado para o coração da agricultura capitalista, altamente mecanizada e racionalizada ${ }^{29}$.

O dualismo assumia formas ainda mais sutis entre os concessionários da CAPER ou entre os

${ }^{28}$ Condutas aparentemente idênticas, como a ajuda mútua e a cooperação, a estocagem e a poupança, a previdência e a previsão estão separadas por um abismo e pertencem a dois sistemas totalmente diferentes entre si. Ver BOURDIEU, 1963.

29 Através desse dualismo, os trabalhadores conseguiam evitar (de maneira quase mágica) o dilaceramento a que teria conduzido o esforço para unificar uma experiência contraditória e dupla. O empregador dos colonos, por sua vez, evidentemente retirava daí vantagens: enquanto permanecesse uma "reserva" cultural, esta reserva de mão-de-obra não colocaria os problemas que uma população de trabalhadores, encorajada por um espírito revolucionário, poria. Além disso, o empregador podia usar os "benefícios em espécie" que concedia aos seus empregados como pretexto para pagar salários muito baixos (cerca de $30 \%$ abaixo do salário mínimo argelino) e para ignorar as limitações da jornada de trabalho. Enfim, esses pedaços de terra forneciam um excelente meio para explorar os trabalhadores, quer prendendo-os graças à aparência de generosidade, quer mantendo-os pela ameaça de privá-los de uma terra que lhes permitia ter a ilusão de serem ainda camponeses independentes. membros das $\mathrm{SCAPCOs}^{30}$. Instalados em terras férteis, dotados dos meios mais modernos de cultivo, eles eram induzidos pelo contexto geral a adotar os objetivos últimos nela inscritos e a buscar, por exemplo, rentabilidade e produtividade. Mas isto não era suficiente para fazê-los renunciar completamente aos fins e valores tradicionais. Demasiado inseguros de si próprios e da sua situação para escolher, eles agiam como se quisessem acumular as vantagens dos dois sistemas, de modo que podiam se vistos perseguindo fins tradicionais com meios modernos ou, inversamente, perseguindo fins modernos com meios tradicionais; ou, mais paradoxalmente ainda, perseguindo fins mutuamente incompatíveis porque tributários de duas lógicas opostas. Se o camponês descamponeisado não pode viver sua condição senão em contradição, isso ocorre porque ele pretendia ter o conjunto de seguranças materiais e morais que a sociedade tradicional (voltada para a satisfação das necessidades imediatas ao menor custo e ao menor risco) lhe assegurava à custa da renúncia da busca do lucro máximo e, ao mesmo tempo, as vantagens que na economia moderna só se adquire à custa de investimentos altos e muito freqüentemente arriscados.

Compreende-se que o camponês argelino encontre nesta dupla referência razões para seu desgosto que, embora incompatíveis, se reforçam e se reiteram mutuamente. Compreende-se também que ele se obstine desesperadamente em fazer a escolha impossível de não escolher entre as duas lógicas: por exemplo, entre os membros das SCAPCOs, os antigos camponeses gostariam de utilizar os meios que estão geralmente a serviço da produção para o mercado (tratores, fertilizantes etc.) para produzir os bens destinados ao seu consumo, como trigo e cevada, por exemplo; outros aspiram utilizar meios modernos para cultivar os seus pequenos e pobres pedaços de terra segundo a lógica tradicional, quer dizer, ignoran-

\footnotetext{
30 A Caisse pour l'Accession à la Propriété et à la Exploitation Rurale (CAPER) foi criada por um decreto das autoridades francesas de 26 de março de 1955. Desde 1958 seu principal objetivo era financiar a reforma agrária prevista pelo Plano Constantine "para a modernização e integração da Argélia", incluindo a compra, melhoria, divisão e alocação de 250000 hectares de terra para 15000 fellah 'in. As Séctions Coopératives Agricoles du Plan de Constantine (SCAPCOs) eram cooperativas agrícolas criadas pelo Plano Constantine [nota de Ethnography].
} 
do qualquer consideração de rentabilidade e de produtividade. Em geral, os antigos camponeses desejam preservar os prazeres da vida na farqa (festas, relações sociais etc.) que evocam com nostalgia, beneficiando-se ao mesmo tempo das vantagens fornecidas pelo rigor racionalizado da lógica capitalista. $\mathrm{E}$ as inconsistências são talvez o que lhes permite suportar (senão ultrapassar) a contradição de que são produto. Pode o camponês descamponeisado de fato se perpetuar enquanto tal a não ser na e por meio da contradição? "Se o camponês calculasse", diz um provérbio cabila, "ele não semearia". Aquele que, tendo feito a conta, continua a plantar, comete um disparate, enquanto que os seus ancestrais, que semeavam sem contar, escapavam pura e simplesmente das influências da lógica econômica. Mais ainda, se ele se esforçasse por modernizar as técnicas empregadas e por racionalizar os modos de produção, não faria mais do que duplicar o absurdo fundamental da sua situação, já que é o próprio fato de continuar a cultivar uma terra pouco rentável que quebra a lógica da economia racional ${ }^{31}$. O camponês "camponeisado" estava adaptado a uma terra da qual esperava, como uma graça, somente os meios para viver ou para sobreviver; o camponês descamponeisado, ao contrário, está condenado à contradição, já que persegue o impossível e que, sabendo disso, não tem outra escolha a não ser a perpetuação dissimulada e fictícia das rotinas tradicionais ou então a inovação que aumenta (sem ultrapassar) a contradição que o espírito calculista faz surgir ${ }^{32}$.

É isto que os economistas esquecem quando denunciam a falta de racionalidade econômica praticada pelos camponeses, e não somente na Argé-

$31 \mathrm{Se}$, entre os agricultores da CAPER de Aïn-Sultan e de Lavarande e da SCPACO do Marabout-Blanc, os antigos fellah'in estão menos descontentes do que os antigos trabalhadores desses mesmos domínios, é porque os primeiros podem encontrar no crescimento relativo dos seus rendimentos uma compensação para o abandono das rotinas tranqüilizadoras, enquanto que os segundos perderam a segurança que o salário regular e a perpetuação do modo de vida tradicional lhes dava, sem para tanto terem conseguido os meios para realizar por conta própria a modernização e a racionalização completa da agricultura que conheciam.

32 Interrogado sobre a utilização de adubo, um fellah' de Matmata respondeu, com um sorriso meio irônico, meio resignado: "Com um arado, usar fertilizante ? É ser muito fresco!" lia. Não será nestes simples lapsos em relação à lógica econômica que os camponeses também extraem o incentivo para prosseguir adiante, por menos rentável que seja sua atividade? É, por exemplo, o mesmo ponto de honra que proíbe o abandono da propriedade ancestral e que leva a condutas baseadas no prestígio capazes de arruinála, crescendo, por vezes, a tentação para a ostentação à medida que a crise da agricultura se agrava.

O camponês descamponeisado não pode ressuscitar a agricultura tradicional; ele só pode, mentindo para si próprio, perpetuar a sua aparência. E isso é tão verdadeiro para os camponeses de Aghbala ou de Djemaâ-Saharidj, como para os cooperados da CAPER ou das SCACPOs, ou para os trabalhadores das propriedade tocadas em regime de auto-gestão. Sem dúvida, porque permanecem mais próximos do camponês tradicional do que do agricultor racional, uns e outros tendem a regressar à condição camponesa ou às suas aparências, mais do que a reinventar o novo sistema de modelos exigido pela adaptação a uma agricultura moderna. E os camponeses das regiões poupadas ao choque direto da colonização não podem continuar ignorarando o caráter ilusório da cultura dos solos leves das terras altas; não podem, além disso, continuar a cultivar os solos mais pesados com os meios tradicionais apropriados a uma buqâa (pequena parcela) ou a um ah'riq (campo) ${ }^{33}$. A contradição está na própria situação, quer porque a terra não pode produzir o suficiente para justificar o uso de técnicas racionais, quer porque não se dispõe dos meios de tirar da terra aquilo que ela poderia produzir.

Mas, mais profundamente, a contradição está nos próprios camponeses. Se o camponês argelino não consegue escolher entre os dois sistemas, e se quer manter ao mesmo tempo as vantagens de um e de outro, é porque não pode apreendê-los enquanto tais: ele tem do sistema econômico moderno, sempre percebido a partir do exterior nas suas manifestações mais exteriores, uma visão necessariamente mutilada, de modo que dele só

\footnotetext{
33 Nos termos empregados pela física de solo, os solos são compostos, principalmente, pelas partículas de areia (fração mais leve), silte (fração intermediária) e argila (fração mais pesada). Logo, "solo leve" é o solo com maior teor de areia (solo de praia ou de deserto) e "solo pesado" é o solo com maior teor de argila (nota da revisão técnica).
} 
pode captar pedaços descontextualizados (cf. BOURDIEU et al., 1963, p. 370-371); do sistema tradicional, não the restam senão fragmentos esparsos e, mais do que um espírito vivo, resistências e temores. Em suma, por incapacidade em falar bem as duas línguas culturais de modo a mantê-las claramente separadas, está condenado às interferências e às contradições que são responsáveis pelo sabir cultural.

\section{O PREGO DE DJEHA ${ }^{34}$}

O sistema de contradições necessárias que o fellah argelino traz consigo não aparece de forma tão manifesta senão quando desaparecem as condições da sua constituição. Enquanto o sistema colonial se perpetuava, o camponês descamponeisado estava condenado a não escolher entre as duas lógicas porque não podia apreendê-las enquanto tais, e porque, se o fizesse, não teria os meios de levar a escolha pela racionalização até suas últimas consequências. O esforço para dominar o futuro só pode ser efetivamente empreendido quando são efetivamente dadas as condições indispensáveis para que seja assegurado um mínimo de chances de sucesso. Quando não é assim, não resta outra atitude possível que não seja o tradicionalismo forçado, essencialmente diferente do tradicionalismo tradicional, porque implica a consciência da possibilidade de agir de outra maneira e a impossibilidade de realizar essa possibilidade.

Com a abolição do sistema colonial, as causas objetivas das contradições da conduta desapareceram, ao menos em parte, visto que os camponeses retomaram a posse da maior parte das terras detidas pelos colonos, sem que com isso desaparecessem todas as contradições. As incoerências que marcavam tanto as condutas como as aspirações dos camponeses da CAPER ou das SCAPCOs remetiam abertamente (talvez de maneira demasiadamente ostensiva) para a contradição contida nessas instituições, negações fictícias do sistema colonial que elas serviam e que as tornavam possíveis. Assim, o observador e os próprios camponeses poderiam esperar de forma sensata que as condutas patológicas desaparecessem com a causa patogênica. Se as contradições que

34 Ao vender uma casa, Djeha (uma figura lendária) pediu que the deixassem, na casa, um prego. Pendurando uma carcaça, todo dia, neste prego, ele logo conseguiu se livrar dos compradores. ameaçavam os esforços de socialização da agricultura eram desconcertantes, isso ocorria porque o contexto histórico mais amplo favorecia (mesmo junto aos principais decisores da política argelina) a esperança ilusória de que, por uma espécie de mutação súbita, a mudança decisiva das condições de existência (e, mais precisamente, no caso da agricultura, dos modos e relações de produção) desencadearia automaticamente uma transformação decisiva das condutas e das ideologias que elas favoreciam ${ }^{35}$. A sedução desta representação ingênua da realidade social e da lógica da sua transformação se exerce com uma força particular sobre uma sociedade que, realizando a sua descolonização ao fim de uma guerra de libertação longa e terrível, procura marcar, por todos os meios, mesmo mágicos, uma ruptura decisiva com um passado vencido e renegado, e, mais precisamente, sobre uma pequena-burguesia intelectual, detentora da maior parte dos postos de autoridade, que, freqüentemente, não tem dos camponeses mais do que uma imagem despojada daquilo que faz a sua essência histórica.

O sistema colonial sobrevive à medida que as contradições que deixa para trás não são efetivamente ultrapassadas, o que supõe que elas devam ser apreendidas e enfrentadas enquanto tais. Ora, a lógica da descolonização (negação que transporta consigo a marca daquilo que nega) leva a pequena-burguesia de burocratas a negar magicamente, como fantasmas envergonhados do colonialismo defunto, as contradições do real, mais do que a esforçar-se para ultrapassá-las graças a uma ação orientada por um conhecimento apropriado do real. Mas a imagem idealista e idealizada do camponês não pode resistir muito tempo ao princípio de realidade, e a crença na espontaneidade revolucionária das massas rurais arrisca-se a ceder lugar a uma concepção mais pessimista, mas não mais realista. Não se vê então opor-se ao "socialismo libertário" (a expressão é de GUÉRIN, 1963) das comunidades autogeridas, ameçado pelas tensões entre as exigências populares e as intervenções burocráticas, um socialismo autori-

\footnotetext{
35 Um dos mais altos responsáveis pela política econômica na Argélia, a quem nós assinalávamos, em março de 1963, a utilidade que tinham, para os organizadores dos comitês de gestão, as lições fornecidas pelo estudo das experiências de cooperação agrícola (CAPER e SCAPCOs) realizadas no tempo da colonização, rejeitou com indignação esta comparação.
} 
tário apoiado pelo Exército?

Em todos os casos, substitui-se o camponês concreto por uma abstração. Na verdade, a seleção arbitrária de aspectos que só existem como elementos de uma realidade contraditória supõe que se dissocie o camponês das condições de existência que fizeram dele o que ele é: é preciso ignorar tudo sobre a condição dos trabalhadores agrícolas e dos camponeses descamponeisados - perseguidos pela incerteza sobre o amanhã, impedidos de encontrar num mundo que os esmaga um começo para a realização das suas esperanças, e não tendo outra liberdade que não seja a de exprimir a sua revolta pela trapaça e pela astúcia quotidianas que corrói pouco a pouco o sentimento de dignidade $^{36}$ - para atribuir qualquer crédito às profecias escatológicas que vêem no campesinato dos países colonizados a única classe verdadeiramente revolucionária ${ }^{37}$.

Ou então se deveria supor, através de uma nova abstração, que os efeitos da exploração econômica e da privação cultural desapareceriam ao mesmo tempo que a sua causa? De fato, sabemos que os diferentes níveis da realidade social não se transformam necessariamente no mesmo ritmo e que as maneiras de agir e de pensar podem sobreviver a uma mudança das condições de existência. O camponês pode ser libertado do colono sem ser libertado das contradições que a colonização incutiu nele.

\section{DUAS ABSTRAÇÕES CONTRADITÓRIAS}

A colonização tirou do camponês argelino mais do que a terra; despojou-o de um bem que não lhe

\footnotetext{
36 Assim, são freqüentemente relatadas, com um espanto escandalizado ou entristecido, as falcatruas ou as fraudes a que cometem os membros dos comitês de gestão (por exemplo, as vendas clandestinas de frutas ou de legumes). Não encontrassem estas condutas justificação ou desculpa no tipo de organização que se impôs aos camponeses e na natureza da relação que eles mantêm com a SAP (Société Algérienne de Prévoyance) ou com o diretor, permaneceriam perfeitamente compreensíveis. Não é verdade que o sistema colonial inculca nos trabalhadores mais desfavorecidos o sentimento de que todos os meios são legítimos, a começar pelo subterfúgio e pela esperteza, as armas dos desarmados, para roubar um momento de descanso ao trabalho duro ou para tentar ganhar algum dinheiro com o mínimo de esforço?

${ }^{37}$ As análises teóricas em que se baseia esta crítica foram plenamente desenvolvidas em BOURDIEU, 1963, especialmente p. 307-312 e p. 350-360.
}

pode ser magicamente restituído ou atribuído e que ele deve não somente refazer, mas fazer: sua cultura. Tendo retomado a posse de uma terra que, uma vez transformada profundamente, apresenta-se a ele como um sistema de exigências objetivas, o fellah encontra-se diante da tarefa de criar o sistema de modelos de comportamento e de pensamento que lhe permitam adaptar-se à nova situação. Enquanto não tiver recuperado a posse de si próprio através da elaboração de uma cultura nova e coerente, o camponês argelino poderá pisar a terra do colono, cultivá-la ou recolher seus frutos, sem tomar verdadeiramente posse dela. Assim como aquelas famílias que, tendo passado rapidamente da favela [bidonville] para um apartamento dotado dos confortos modernos, não chegam a tomar posse do espaço a eles atribuído e favelizam o local porque não podem modernizar seu modo de vida, pois não dispõem dos recursos necessários e não são capazes de adotar o sistema de condutas e atitudes que a habitação moderna exige ${ }^{38}$, os camponeses descamponeizados correm o risco de tornar a sistemas de adaptação mais rudimentares, mas mais seguros, seja pela reintrodução de técnicas e costumes agrários mais tradicionais, seja porque tendem a comportar-se como simples operários que não esperam do seu trabalho mais do que um salário.

Os partidários do socialismo autoritário e os defendores do socialismo libertário podem encontrar numa dupla realidade os argumentos favoráveis à representação abstrata, porque parcial, que fazem do real. Os campeões da "democracia a partir das bases" (segundo a expressão oficial) podem invocar, corretamente, a aspiração dos camponeses de tomar posse das terras do colono e a geri-las como proprietários. Mas a própria organização dos comitês de gestão (instituídos pelo nascente Estado argelino) não vai contra essa expectativa? Com efeito, os camponeses vêem com muita impaciência as ingerências múltiplas e freqüentemente desajeitadas dos inumeráveis tutores que os rodeiam com uma solicitude incômoda - prefeituras e sub-prefeituras, organizações locais do partido, a UGTA (União Geral dos Trabalhadores Argelinos), "diretores" ou "administradores", o SAP 39 etc. Em muitos casos, a

38 Esse ponto é desenvolvido em BOURDIEU, 1977, cap. 1 (nota de Ethnography).

${ }^{39}$ Aos olhos do camponês, a Société Algérienne de 
relação com o burocrata instituído pela autoridade central, percebido como um "estrangeiro", um homem da cidade ou um intruso, é, para os antigos trabalhadores agrários, a ocasião para atualizar a relação que mantinham com o colono ou, melhor, com os engenheiros agrônomos da CAPER ou das SCAPCOs.

É que, aos olhos do camponês, a posse da terra permanece abstrata e fictícia se não se concretiza como "domínio da terra", quer dizer, como liberdade para organizar soberanamente todos os momentos da atividade agrícola, da produção à comercialização ${ }^{40}$. As limitações de poder e as interferências alteram o sentimento de posse e o levam, incerto da sua relação com a terra que cultiva, a comportar-se como no passado, como um simples assalariado; ou então, mesmo se todas as garantias lhe são dadas, ele tem a sensação de estar sendo roubado, menos nos seus rendimentos e lucros e mais nos seus direitos de proprietário $^{41}$. Em suma, o socialismo libertário arrisca-se a atingir fins opostos àqueles que persegue explicitamente e a restituir os camponeses à condição de trabalhadores tão pouco empenhados quanto possível em um trabalho cuja organização abandonam a outros e de que apenas esperam um salário regular.

Prévoyance encarna o passado colonial: entre outras coisas, uma política de crédito rural mal adaptada tinha feito com que ela aparecesse freqüentemente como uma reencarnação da usura tradicional. Estava portanto predisposta a desempenhar o papel de bode expiatório. Sua função atual não pode senão reforçar essa imagem: encarregada de armazenar as colheitas, de vendê-las, de repartir os lucros, de organizar o uso dos equipamentos agrícolas e dos créditos, ela usurpa constantemente aquilo que os camponeses consideram ser suas prerrogativas

40 Se a comercialização dos produtos suscita tantas resistências, é talvez porque sua venda no mercado é um dos direitos mais exclusivos do "dono da terra", geralmente o mais velho. É também porque ela é objeto de atitudes contraditórias, o camponês hesitando entre a nostalgia da produção para o consumo familiar e a busca do lucro; e, também, é claro, porque esta operação facilmente propicia pretextos para toda sorte de desconfiança.

41 Entre os camponeses da CAPER, a questão era sempre a mesma: "Quem é o dono desta terra?" Os constrangimentos que pesavam sobre eles, quer se tratasse da escolha das culturas, das formas de cultivo ou da comercialização dos produtos, apareciam-lhes como uma negação incontestáve das declarações segundo as quais eram eles os "proprietários da terra".
A decisão que padroniza os salários em 7 fran$\cos$ ao dia, quaisquer que sejam a quantidade e a qualidade do trabalho prestado, só pode agir na mesma direção. De fato, os camponeses são suficientemente versados na prática do cálculo econômico para medir espontaneamente a quantidade do trabalho fornecido (segundo a sua qualidade) em relação à remuneração recebida: sabe-se que em muitos lugares os operários, outrora pagos por tarefa, reduziram a sua produção proporcionalmente à redução do seu salário; sabe-se também que o nivelamento dos salários, apesar das diferenças de qualificação, suscita resistências. E será suficiente apresentar o salário diário como um adiantamento do lucro para que os membros do comitê de gestão se interessem pelo projeto coletivo? Com efeito, é pedir ao camponês que adote em relação à atividade agrícola uma atitude que lhe é também tão pouco familiar quanto possível; o seu ceticismo, longe de exprimir somente sua desconfiança diante do Estado, encarnado pelo diretor, é constitutivo da sua atitude em relação ao futuro. Mais ainda, como se pode exigir dele, sem uma longa educação prévia, que compreenda e manipule noções tão complexas e tão profundamente estranhas à sua tradição cultural como as de cooperação e de lucro coletivo ${ }^{42}$, que saiba distinguir entre custos operacionais, investimentos na agricultura coletiva e os investimentos de interesse comum, ou mesmo, mais simplesmente, entre a renda obtida pela venda das colheitas e o lucro líquido?

\footnotetext{
$\overline{42}$ No vale de Soummami, uma cooperativa substituiu os empresários que costumavam manipular a compra de figos dos produtores. Como o preço de compra só devia ser fixado após determinado o lucro líquido, os camponeses só recebiam um adiantamento por conta do valor da sua produção. Contudo, na ausência de uma campanha de informação, a kubiratif era tida como um comerciante entre outros ou, melhor, como um comerciante oficial dotado do apoio da "repartição pública" (local), o que suscitava certa desconfiança. Mas a confusão será melhor avaliada se se souber que a cooperativa era constituída por antigos comerciantes de figo: nestas condições, como os camponeses aceitariam vender sua produção sem antes passarem pelo regateio tradicional, sem terem promovido a concorrência entre compradores, sem, sobretudo, terem fixado de uma vez por todas o preço do quintal de figos e sem estarem seguros de receber imediatamente o dinheiro da venda do produto? Compreende-se que tenham sido poucos os camponeses que negociaram a sua produção com a cooperativa, e que todos os outros tenham preferido vendê-la a compradores clandestinos que pagavam 80 francos o quintal.
} 
Confrontado com o teste da realidade, esse sistema, inspirado em uma ideologia populista, está se convertendo em seu oposto, uma organização autoritária. A autogestão está gradualmente - e de forma muito lógica - sendo substituída por aquilo que os juristas romanos chamavam de negotiorum gestio: o tutor, isto é, o Estado, na pessoa do diretor, do administrador ou da SAP, age no lugar do pupilo, que não saiu ainda da menoridade. Seu poder está limititado à obrigação de prestar contas. E pode-se perguntar se a "desconfiança camponesa”, que tanto evocam os críticos, não será afinal a resposta a uma desconfiança inconfessada em relação ao camponês real, desconfiança que se dissimula sob a aparência da generosidade e do respeito em relação ao camponês fictício e, podese dizer, ideal.

Os partidários do socialismo autoritário podem encontrar os seus melhores argumentos na constatação das contradições que a autogestão engendra: tratar explícita e deliberadamente os trabalhadores como simples assalariados, totalmente excluídos da gestão e da partilha dos lucros, é, pelo menos, poupar-se das ambigüidades ou da má fé das eleições "orientadas" ou dos conflitos e tensões entre os representantes eleitos dos trabalhadores e os burocratas; é, neste mesmo sentido, ganhar em rendimento e rentabilidade, como a experiência tem mostrado em muitos casos. Além disso, da mesma maneira que se pode argumentar, em defesa da autogestão, que ela visa satisfazer a aspiração muito viva dos camponeses para cultivar as terras retomadas dos colonos como suas terras, também os partidários do socialismo autoritário podem justificar-se com o fato de que os camponeses descamponeisados aspiram à segurança que lhes é dada por um salário regular e pela condição de "operários-camponeses".

Sem dúvida que esse tipo de organização tem o mérito de apresentar-se por aquilo que é; mas ela não tenderá a substituir pura e simplesmente o colono por uma burocracia estatal? Que benefício duradouro terão tido os antigos trabalhadores agrícolas com a independência, senão o de poder persuadir-se de que aceitam os seus baixos salários por um sacrifício gratuito e em nome da revolução? Deverá surpreender que eles permaneçam surdos em relação à exaltação da "consciência socialista"? Que, comportando-se como simples assalariados movidos unicamente pela maximização do lucro, meçam o seu esforço pelo rendimento monetário que dele retiram e que, na sua luta velada contra o Estado-patrão, usem as armas tradicionais do subproletariado, a esperteza ou mesmo a fraude ${ }^{43}$ ? Seria um exagero dizer que a pequena-burguesia letrada usa cinicamente a linguagem revolucionária como um instrumento de exploração. Contudo, não há dúvida de que o socialismo autoritário, isto é, centralizado e burocrático, para o qual tendem, por uma escolha explícita, ou pela força das coisas, as diferentes experiências argelinas, não pode senão servir aos interesses dessa pequena-burguesia que tem interesse na burocratização, dando uma justificação técnica e ideológica à sua autoridade e aos seus privilégios e colocando-a ao abrigo das exigências impacientes e freqüentemente incoerentes dos subproletários dos campos e das cidades.

Mas, além disso, se é sabido que o rendimento individual médio dos agricultores era, em 1960, de 160 francos por mês, e o dos assalariados agrícolas, de 132 francos (para o conjunto da Argélia) e, mais precisamente, que $87,1 \%$ dos agricultores e $89,4 \%$ dos trabalhadores agrícolas tinham um rendimento mensal inferior a 200 francos, vêse claramente que, com os seus 7 francos por dia (210 francos por mês) aos quais se acrescentam os abonos e, eventualmente, uma parte dos lucros, os fellah'in das propriedades em regime de autogestão não podem deixar de parecer privilegiados aos olhos dos trabalhadores eventuais, dos khamnés, dos pequenos camponeses subempregados e da massa dos indivíduos parcial ou supostamente ocupados. Para todos aqueles que não obtiveram da independência aquilo que dela esperavam, a saber, a terra, a decepção já é grande; do mesmo modo, a tensão não pode deixar de aumentar entre os "privilegiados" dos domínios autogeridos e os trabalhadores sazonais, excluídos de certo número de vantagens econômicas e políticas (por exemplo, a eleição de deputados). Assim, ainda que a aposta econômica e política nas experiências de autogestão seja imensa, visto que dela depende o futuro da agricultura moderna e a possibilidade de inventar uma organização simultaneamente justa e eficaz das relações de produção, o setor autogerido não deve e não pode ser considerado como um mundo à parte. Deixar instaurar-se uma disparidade demasiado marcada entre uma agricultura rica, assegu-

43 O que vale, evidentemente, para todos os comitês de gestão, onde, devido à ingerência da burocracia, a participação dos trabalhadores é fraca. 
rando rendimentos regulares e relativamente elevados a uma minoria de trabalhadores permanentes, e a grande massa da população rural, é perpetuar, sob uma outra forma, a contradição que paira sobre a sociedade colonial e acelerar a descamponeização, fazendo aparecer como inscrita na natureza das coisas a dualidade de dois tipos de agricultura e acabando por convencer os fellah'in situados nas margens das terras ricas que estão irremediavelmente condenados à economia de subsistência e ao tradicionalismo do desespero.

\section{OEDUCADOR E O BUROCRATA}

Mas, no fim das contas, em que medida os objetivos de uma política racional são compatíveis com os fins contraditórios que o camponês argelino traz consigo em estado virtual? Por razões ao mesmo tempo políticas e econômicas, uma ação racional deve conciliar meios e fins que podem estar em contradição sem serem intrinsecamente incompatíveis: em primeiro lugar, a intervenção da autoridade central parece indispensável e, de qualquer maneira, inevitável, seja ela cumprida por meio de uma burocracia, seja por meio de um sindicato, de um partido ou de um corpo de técnicos.

Isso acontece porque, deixados por conta própria, os camponeses assentados nas grandes propriedades abandonadas pelos colonos e, a fortiori, pelos demais, estão propensos a manterem-se fiéis ao modo de produção mais tradicional, por falta de meios técnicos e financeiros que, e eles sabem disso, constituem a condição necessária da modernização e da racionalização e também porque toda a sua atitude em relação ao mundo (ligada às suas condições de existência pela mediação da consciência que têm delas) e toda a sua tradição cultural tendem a fazer com que escolham maximizar a segurança, ainda que em detrimento do lucro, ao invés de maximizar o lucro em detrimento da segurança. Não se viu, por exemplo, no vale de Soummam, camponeses organizados espontaneamente em comitês de gestão dividir a propriedade de um colono em lotes capazes de alimentar uma família e cultivar aí, segundo as técnicas mais tradicionais, trigo, cevada e feijão, até a intervenção da autoridade central ${ }^{44}$ ?

${ }^{44} \mathrm{O}$ tradicionalismo do camponês, na sua forma tradicio-
nal ou na sua forma regressiva, e o ethos que lhe é solidário,
não podem deixar de entrar em conflito com o esforço para
A intromissão, entretanto, não pode limitar-se à esfera econômica, visto que as escolhas econômicas são também, e antes de tudo, escolhas culturais. Encerrado na contradição, o camponês não pode, fundamentalmente, ter uma representação adequada da sua condição e, menos ainda, das contradições dessa representação. Assim, cabe a uma elite revolucionária definir com ele (e não para ele) o que ele deve ser em uma e para uma ação orientada segundo uma teoria sistemática e realista, quer dizer, levando em conta todos os aspectos, mesmo se contraditórios, do que ele realmente é.

Contudo, o meio requerido para o cumprimento dos fins econômicos e culturais, a saber, a intervenção externa, não é passível de entrar em contradição com os próprios fins que este meio supostamente deve servir? Se é verdade, como vimos, que o camponês identifica a "posse da terra", a condição da sua adesão, com a liberdade de fazer o seu trabalho como lhe convém, é evidente que uma interferência destinada a organizar e a estimular a atividade conforme os imperativos econômicos e culturais definidos anteriormente corre o risco de não contar com a participação dos camponeses. Isso quer dizer que se deve e se pode escolher? De fato, como realizar uma revolução econômica e uma revolução cultural sem a participação entusiasta das massas? Não se trata, nos dois casos, de criar uma nova ética exaltando a produtividade e o espírito de sacrifício?

Só uma ação educativa, inclusiva e total, pode ultrapassar as contradições sem as negar magicamente pela conciliação fictícia dos contrários. Essa ação supõe, em primeiro lugar, uma definição clara e realista dos fins perseguidos - em suma, uma teoria sistemática da realidade econômica e social, fundamento de um programa metódico e progressivo. Mas a tarefa de cada educador particular não pode deixar-se definir pela letra de um regulamento que prevê todos os casos particulares: em uma situação revolucionária, o educador deve

instaurar uma organização racional da produção e das relações de produção. Daí resulta que a consideração da racionalidade econômica tanto quanto a exaltação revolucionária do espírito de sacrifício levam necessariamente a combater a volta às tradições culturais mais enraizadas, como o espírito de clã ou o nepotismo, que constituem um obstáculo à gestão racional do empreendimento, provocando conflitos ou favorecendo o fechamento cada unidade econômica em si mesma. 
criar, dia-a-dia, o conteúdo e a forma da sua ação prática (quer dizer, de incitação e de organização) e a sua formação prévia deve fornecer-lhe primordialmente os meios de operar essa criação contínua. A especificidade da ação educativa, na sua forma ideal, é precisamente a de se adaptar às aptidões e expectativas daqueles que procura elevar e transformar, portanto de conhecê-los e respeitá-los; de definir, em cada caso, um sistema de exigências ajustadas a essas aptidões e expectativas, assim como à sua transformação sob a influência da ação educativa; em suma, de impedirem-se de propor arbitrariamente exigências definidas abstratamente para assuntos abstratos. Assim, a ação centralizada de uma burocracia rí- gida seria substituída por uma ação particularizada, porque diretamente adaptada a situações particulares e a sujeitos particulares. É no confronto permanente entre as expectativas dos camponeses e as exigências das elites, responsáveis pela determinação e pela realização progressiva de fins racionais, que pode elaborar-se uma cultura autêntica, sistema de modelos de comportamento econômico e social simultaneamente coerente e compatível com as condições objetivas. Se as elites revolucionárias quiserem cumprir essa tarefa é, seguramente, delas próprias que deverão exigir tais virtudes excepcionais que, hoje, elas esperam dos camponeses e, muito freqüentemente, apenas deles.

Pierre Bourdieu ocupou a cadeira de Sociologia no Collège de France, onde dirigiu também o Centro de Sociologia Européia e editou a revista Actes de la recherche en sciences sociales até sua morte, em 2002. Ele é autor de vários livros clássicos em Sociologia e Antropologia, incluindo La Reproduction: éléments d'une théorie du système d'enseignement (com Jean-Claude Passeron; 1970), Esquisse d'une theorie de la pratique (1972), La Distinction: critique sociale du jugement (1979), Ce que parler veut dire: économie des échanges linguistiques (1982) Homo Academicus (1984), La Noblesse d'État. Grandes écoles et esprit de corps (1989) e Les règles de l'art: genèse et structure du champ littéraire (1992). Dentre seus estudos etnográficos estão: Le déracinement: la crise de l'agriculture traditionnelle en Algérie (com Adbelmalek Sayad, 1964), Algérie 60: structures économiques et structures temporelles (1977), La misère du monde (1993) e Le Bal des célibataires: crise de la societé em Béarn (2002).

Abdelmalek Sayad, sociólogo de origem cabila, foi Diretor de Estudos do Centre National de la Recherche Scientifique e pesquisador no Centro de Sociologia Européia até sua morte, em 1998. Ele foi um dos primeiros estudantes e colaboradores de Pierre Bourdieu na Argélia no final dos anos 1950 e devotou sua vida ao estudo histórico e antropológico das migrações franco-argelinas e aos seus impactos em ambas as sociedades. Seus trabalhos mais importantes incluem: com Pierre Bourdieu: Le déracinement: la crise de l'agriculture traditionnelle en Algérie (Paris: Minuit, 1964); L'immigration, ou les paradoxes de l'altérité (De Boeck Université, 1992); com Eliane Dupuy: Un Nanterre algérien, terre de bidonvilles (Paris: Autrement, 1998); Histoire et recherche identitaire suivi de Entretien avec Hassan Arfaoui (St.Denis: Bouchène, 2002); A imigração ou os paradoxos da alteridade (São Paulo: USP, 1999) e La double absence. Des illusions de l'émigré aux souffrances de l'immigré (Paris: Seuil, 1999).

\section{REFERÊNCIAS BIBLIOGRÁFICAS}

BASTIDE, R. 1960. Les religions africaines $d u$ Brésil. Vers une sociologie des interpénétrations de civilisations. Paris: PUF.

BENEDICT, R. 1934. Patterns of Culture. Boston: H. Mifflin.

BOURDIEU, P. 1962. La hantise du chômage chez l'ouvrier algérien. Prolétariat et système colonial. Sociologie du travail, n. 4, p. 313331.

1963. La société traditionnelle: attitude à l'égard du temps et conduite économique. Sociologie du travail, n. 1, p. 24-44, jan.-mars.

1973. The Algerian Subproletariate. In: ZARTMAN, I. W. (ed.). Man, State, and Society in the Contemporary Maghrib. London: Pall Mall.

1977. Algérie 60, structures économiques et structures temporelles. Paris: Minuit.

BOURDIEU, P.; DARBEL, A.; RIVET, J.-P. \& SEIBEL, C. 1963. Travail et travailleurs en 
Algérie. Paris: Mouton.

CHEVALIER, R. 1961. La centuriation et les problèmes de la colonisation romaine. Études rurales, n. 3, p. 54-80, août-déc.

DARBEL, A. 1960. La consommation des familles en Algérie. Paris: PUF.

DE BROGLIE, A. 1860. Une réforme administrative en Algérie. Paris: Pas de la M.

GUÉRIN, D. 1963. Algérie: 1'autogestion menacée. France-Observateur, Paris, n. 19, déc.

ISNARD, M. H. 1960. Structures de l'agriculture musulmane en Algérie à la veille de l'insurrection. Méditerranée, n. 2-3, p. 49-59, avr.-sept.

JACOB, A. 1961. Fin d'une guerre d'Algérie. Études méditerranéennes, n. 9, p. 33-34, automne.

LACHERAF, M. 1960. Constances politiques et militaires dans les guerres coloniales d'Algérie
(1830-1960). Les Temps Modernes, n. 177, p. 727-800, déc.

LÉVI-STRAUSS, C. 1955. Tristes tropiques. Paris: Plon.

MATHIAS, G. 1998. Les Sections Administratives Spécialisées en Algérie. Entre idéal et réalité (1955-1962). Paris: Harmattan.

NOUSCHI, A. 1962. La naissance $d u$ nationalisme algérien. Paris: Minuit.

SLNA. 1950. L'Algérie du demi-siècle. Argel: Services de Liaisons Nord-Africaines.

TALBO-BERNIGAUD, J.-P. 1960. Les zones interdites. Les Temps Modernes, n. 177, p. 709726, déc.

VAISSIÈRE, C. 1863. Les Ouled Rechaïch. Argel: mimeo.

VIDAL-NAQUET, P. 1961. La raison d'État. Paris: Minuit.

\section{OUTRAS FONTES}

JORF (Journal Officiel de la République Française). 1961. Édition des documents administratifs. Paris, v. 8 , n. 8 , mars. 
COLONIAL RULE AND CULTURAL SABIR

Pierre Bourdieu (Collège de France) and Abdelmalek Sayad (Centre national de la recherche scientifique, Paris, France)

The French policy of 'resettlement' of Algerian peasants, designed to undercut popular support for the nationalist war of liberation (1954-62), led to the displacement of one-fourth of the indigenous population of Algeria in 1960. By disciplining space and rigidly reorganizing the life of the fellahin under the sign of the uniform, the French military hoped to tame a people, but it only completed what early colonial policy and the generalization of monetary exchanges had started: the 'depeasantization' of agrarian communities stripped of the social and cultural means to make sense of their present and get hold of their future. War thus accomplished the latent intention of colonial policy, which is to disintegrate the indigenous social order in order to subordinate it, whether it be under the banner of segregation or assimilation. But imperial domination also produces a new type of subject containing within himself or herself the contradictions born of the clash of civilizations: the patterns of behavior and economic ethos imported by colonization coexist inside of the exiled Algerian peasant with those inherited from ancestral tradition, fostering antinomic conducts, expectations, and aspirations. This double-sidedness of objective and subjective reality threatened to undermine the efforts to socialize agriculture after independence, as the logic of decolonization inclined the educated petty bourgeoisie of bureaucrats to magically deny the contradictions of reality as shameful ghosts of a dead colonial past.

KEYWORDS: colonialism; war; peasantry; uprooting; French imperialism; Kabyle culture; Algeria. 
LA DOMINATION COLONIAL ET LE SABIR CULTUREL

Pierre Bourdieu (Collège de France) et Abdelmalek Sayad (Centre national de la recherche scientifique, Paris, France)

La politique française de« regrupement » des paysans algériens, mise en oeuvre pour miner l'appui populaire à la guerre de libération nationale (1954-1962), a provoqué le déplacement d'un quart de la population native de l'Algérie en 1960. En disciplinant l'espace et en aménageant rigoureusement la vie des fellahin, les militaires français espéraient dominer un peuple, mais cela n'a fait qu'achever ce que la première politique coloniale et la généralisation des échanges monétaires avaient déjà entrepris : la « dépaysannisation » de communautés agraires dépouillées de tous les moyens sociaux et culturels qui donnaient du sens à leur présent et qui réglaient leur futur. Ainsi, la guerre a accompli l'intention secrète de la politique coloniale : la désintégration de l'ordre social local dont l'objectif était de le soumettre, soit sous le drapeau de la ségrégation, soit sous le drapeau de l'assimilation. Mais la domination impériale produit aussi un nouvel sujet qui porte les contraditions issues du choc des civilisations : les modèles de comportement et d'ethos économique importés par la colonisation et ceux hérités de la tradition ancestrale cohabitant chez le paysan algérien exhilé, ce qui fait naître des attitudes, des attentes et des aspirations antinomiques. Cette double dimension de la réalité, objective et subjective, menaçait miner les efforts de socialisation de l'agriculture après l'indépendance, tandis que la logique de la décolonisation amenait la petite bourgeoisie lettrée des bureaucrates à nier par magie les contradictions de la réalité comme des fantasmes honteux d'un passé colonial mort.

MOTS-CLÉS : colonialisme; guerre; paysannat; déracinement; impérialisme français; culture kabyle; Algérie. 